\title{
Understanding and Addressing Vaccine Hesitancy in the Context of COVID-19: Development of a Digital intervention
}

Holly Knight ${ }^{1}$; Ru Jia ${ }^{1}$; Kieran Ayling ${ }^{1}$; Katherine Bradbury ${ }^{2,3}$; Katherine Baker $^{2}$; Trudie Chalder $^{4}$; Joanne R Morling ${ }^{1,5}$; Lindy Durrant ${ }^{1}$; Tony Avery ${ }^{1}$; Jonathan Ball ${ }^{6}$; Caroline Barker $^{2}$; Robert Bennett ${ }^{7}$; Tricia McKeever ${ }^{1}$; Kavita Vedhara ${ }^{1}$

${ }^{1}$ University of Nottingham, School of Medicine, Nottingham, UK

${ }^{2}$ National Institute of Health Research (NIHR) ARC Wessex

${ }^{3}$ University of Southampton, Department of Psychology, Southampton, UK

${ }^{4}$ Kings College London, Department of Psychological Medicine, London, UK

${ }^{5}$ National Institute of Health Research (NIHR) Nottingham Biomedical Research Centre (BRC), Nottingham University Hospitals NHS Trust and the University of Nottingham, Nottingham, UK

${ }^{6}$ University of Nottingham, School of Life Sciences, Nottingham, UK

${ }^{7}$ Rehab Studio LTD, London, UK

Corresponding author:

Professor Kavita Vedhara

School of Medicine

University of Nottingham

University Park

Nottingham, NG7 2RD

kavita.vedhara@nottingham.ac.uk 


\begin{abstract}
Background

Severe Acute Respiratory Coronavirus 2 (SARS-CoV-2) was identified in late 2019, spreading to over 200 countries and resulting in almost two million deaths worldwide. The emergence of safe and effective vaccines provides a route out of the pandemic, with vaccination uptake of $75-90 \%$ needed to achieve population protection. Vaccine hesitancy is problematic for vaccine rollout; global reports suggest only $73 \%$ of the population may agree to being vaccinated. As a result, there is an urgent need to develop equitable and accessible interventions to address vaccine hesitancy at the population level.

Method
\end{abstract}

We report the development of a scalable digital intervention seeking to address COVID-19 vaccine hesitancy and enhance uptake of COVID-19 vaccines. Guided by motivational interviewing (MI) principles, the intervention includes a series of therapeutic dialogues addressing 10 key concerns of vaccine hesitant individuals. Development of the intervention occurred linearly across four stages. During stage 1, we identified common reasons for COVID-19 vaccine hesitancy through analysis of existing survey data, a rapid systematic literature review, and public engagement workshops. Stage 2 comprised qualitative interviews with medical, immunological, and public health experts. Rapid content and thematic analysis of the data provided evidence-based responses to common vaccine concerns. Stage 3 involved the development of therapeutic dialogues through workshops with psychological and digital behaviour change experts. Dialogues were developed to address concerns using MI principles, including embracing resistance and supporting self-efficacy. Finally, stage 4 involved digitisation of the dialogues and pilot testing with members of the public. 
medRxiv preprint doi: https://doi.org/10.1101/2021.03.24.21254124; this version posted April 22, 2021. The copyright holder for this preprint (which was not certified by peer review) is the author/funder, who has granted medRxiv a license to display the preprint in perpetuity.

All rights reserved. No reuse allowed without permission.

\section{Discussion}

The digital intervention provides an evidence-based approach to addressing vaccine hesitancy through MI principles. The dialogues are user-selected, allowing exploration of relevant issues associated with hesitancy in a non-judgmental context. The text-based content and digital format allow for rapid modification to changing information and scalability for wider dissemination. 


\section{Understanding and Addressing Vaccine Hesitancy in the Context of COVID-19: Development of a Digital intervention}

\section{Background}

Severe Acute Respiratory Coronavirus 2 (SARS-CoV-2) was identified in late 2019. At the time of writing, the latest estimates suggest that it has spread to over 200 countries and has resulted in the deaths of almost two million people.[1] The resulting global pandemic has seriously affected the social and economic fabric of societies everywhere and the physical and mental health crisis continues.[2] Safe and effective vaccines provide a route out of this crisis, but the development of these vaccines, while necessary, are not sufficient. For vaccines to achieve their full potential, the public also need to be willing to be vaccinated. Recent data suggest this cannot be assumed. A recent international survey indicated that, globally, $73 \%$ of the population would agree to being vaccinated.[3] This estimate should be viewed against a backdrop of declines in vaccine intent overall and the fact that it masks large variations in intent between countries, genders and across age and ethnic groups.[3-5] Vaccine hesitancy, defined as a "delay in acceptance or refusal of vaccines despite availability of vaccine services" [6] may significantly impact uptake of COVID-19 vaccines, particularly amongst ethnic minorities, women, and those with less education [7]. If, as has been suggested, 75$90 \%$ of a population will need to be vaccinated for community protection to be achieved,[8] then there is an urgent need to develop equitable and accessible interventions to address vaccine hesitancy at the population level.

Attempts to improve vaccine uptake are not new and have focussed traditionally on approaches such as information/education, incentives [9-11] and reminders. However, results from successive reviews suggest that the evidence-base in support of any one approach remains limited.[9-12] Furthermore, much of the work has been conducted in the context of 
adults making decisions for their dependents, rather than adults making decisions for themselves. The generalisability of these findings to COVID-19 vaccines in adults is, therefore, unclear. Nonetheless, much can be gleaned from the existing evidence: information, while necessary, is unlikely to improve vaccine uptake on its own, and interventions need to engage with individuals' reasons for hesitancy i.e., their hesitancy cognitions.[13]

We report here on the development of a scalable digital intervention which seeks to address the concerns of individuals who are vaccine hesitant with a view to enhancing the uptake of COVID-19 vaccines. We report the process we followed in developing a digital vaccine hesitancy intervention suitable for adults considering a COVID-19 vaccination. In view of the urgency of the public health need, our approach to intervention development was pragmatic and took advantage of existing data where possible and appropriate.

\section{Methods and Results}

Our development involved four main stages and included involvement of public and patient partners throughout:

Stage 1: In order to understand and identify common reasons for COVID-19 vaccine hesitancy and acceptance we carried out a) an analysis of existing survey data collected during the pandemic, b) a rapid systematic literature review and c) an examination of qualitative findings from a series of public engagement workshops regarding immune challenges and vaccines.

Stage 2: We synthesised evidence from independent experts. This entailed qualitative interviews with experts from a range of relevant disciplines to identify evidence-based responses to the most common vaccine concerns raised by the public identified in stage 1 . 
Stage 3: We developed 'therapeutic dialogues' to address common vaccine hesitancy concerns. These were developed in a workshop bringing together experts in psychological and digital behaviour change interventions.

Stage 4: The digital intervention was developed.

As this was a linear process with each stage informing the next, we present the methods and results from each stage consecutively.

\section{Stage 1: Understanding and identifying common reasons for hesitancy \& acceptance.}

\subsection{Analysis of existing survey data}

As part of an ongoing longitudinal study[14] into the UK population's mental and physical health over the course of the pandemic, we collected data regarding COVID-19 vaccination intention between $11^{\text {th }}-30^{\text {th }}$ November 2020 . This included whether participants intended to get the vaccine and a free text response to elaborate on their main reasons for this intention. Free text responses were analysed for common themes and the frequency at which these themes appeared was quantified. Where vaccine hesitancy was indicated, themes were also categorised within the WHO 3Cs model of vaccine hesitancy, which proposes that three main factors influence the decision to accept vaccines: confidence, complacency, and convenience[6] Coding and categorisation was conducted independently by two researchers (RJ, KA) with high levels of initial agreement (91\% for reasons associated with vaccine hesitancy and $85 \%$ for reasons associated with agreement to vaccination). All discrepancies were resolved by discussion.

A total of $n=762$ individuals provided data $(22 \%$ of whom indicated they were hesitant about receiving a COVID-19 vaccination); 93\% ( $\mathrm{n}=709)$ of respondents also provided a free-text response indicating their reasons for vaccine acceptance or hesitancy, of which $96 \%(\mathrm{n}=683)$ provided sufficient detail for reasons to be categorised into themes. For those who expressed 
vaccine hesitancy, the most common concerns were found to map on to the WHO 3C category of 'confidence' (e.g., concerns related to long term complications, side effects and insufficient testing of the vaccines). The second most common concerns related to 'complacency' (e.g., beliefs of low personal risk of COVID-19, beliefs in ability to fight off the infection naturally). Concerns related to the 'convenience' category were the least common, and centred on a lack of information about the vaccines and altruism (i.e., other people needing the vaccines more) (see Table 1a). In contrast, in respondents who indicated they would be willing to receive a COVID-19 vaccine, the common reasons given related to 'self-protection', followed by 'hope to end the pandemic/wish for normal life' and a desire to 'protect the population or unspecified others and control the virus' (see Table 1b). 
Table 1a: Common reasons for vaccine hesitancy and acceptance: survey findings

\begin{tabular}{|c|c|c|c|}
\hline $\begin{array}{l}\text { WHO 3C } \\
\text { category }\end{array}$ & Themes & Count & Examples of free text responses \\
\hline & Concerns about side effects & 39 & $\begin{array}{l}\text { "I don't have full information about its side effects" } \\
\text { "Undiscovered side effects/uncertainty of the side effects" } \\
\text { "Unknown long-term side effects" }\end{array}$ \\
\hline
\end{tabular}




\begin{tabular}{|c|c|c|}
\hline $\begin{array}{l}\text { Concerns the development of the vaccine has } \\
\text { been rushed }\end{array}$ & 27 & $\begin{array}{l}\text { "Its development and production has been rushed through" } \\
\text { "Feels rushed compared to normal vaccine standards" } \\
\text { "I don't think there has been sufficient time to know fully the effects } \\
\text { of it" }\end{array}$ \\
\hline $\begin{array}{l}\text { Concerns about the safety of the vaccine (but } \\
\text { not explicitly side effects) }\end{array}$ & 21 & $\begin{array}{l}\text { "I'm concerned about its safety" } \\
\text { "Would want to be } 100 \% \text { sure it was safe" } \\
\text { "Would only take it if I was convinced it was } 100 \% \text { safe" }\end{array}$ \\
\hline Unsure about vaccine effectiveness & 14 & $\begin{array}{l}\text { "I would like the research evidence about its effectiveness rate (in } \\
\text { different age groups especially 60+)" } \\
\text { "Not sure about how effective are they, especially as if you get } \\
\text { COVID you can get it again. The vaccines antibodies are not as } \\
\text { effective as getting the virus itself" } \\
\text { "Would prefer a vaccine that stops transmission, not just stop me }\end{array}$ \\
\hline
\end{tabular}




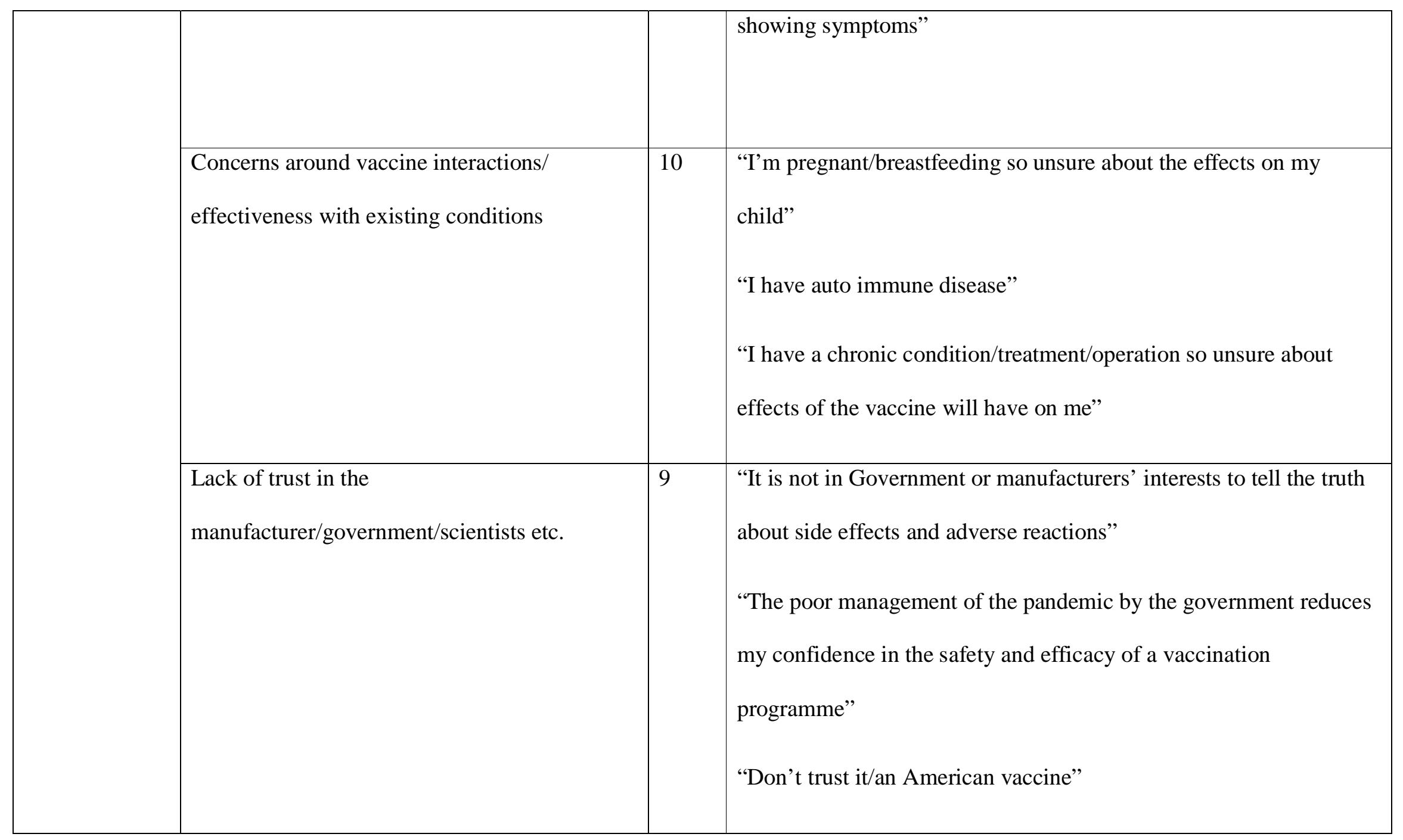




\begin{tabular}{|c|c|c|c|}
\hline \multirow[t]{3}{*}{ Complacency } & Believe they are not at high risk of COVID-19 & 7 & $\begin{array}{l}\text { "I'm not in a risk category" } \\
\text { "I don't want it at this stage as I'm not at high risk of getting } \\
\text { COVID" }\end{array}$ \\
\hline & $\begin{array}{l}\text { Believe they are in good health / Their body } \\
\text { can fight off the virus }\end{array}$ & 6 & $\begin{array}{l}\text { "I prefer my body to deal with it in its own way" } \\
\text { "I believe maintaining strong immune system is best defence" } \\
\text { "I am not in a risk category and I limit my vaccinations to things } \\
\text { that potentially have very serious consequences for me" }\end{array}$ \\
\hline & Have already had COVID-19 & 3 & $\begin{array}{l}\text { "I've had COVID already so should be okay for a few months at } \\
\text { least" } \\
\text { "Would like to know more about antibodies and the likelihood of } \\
\text { getting COVID twice" } \\
\text { "I'd want to know if I have the antibodies already" }\end{array}$ \\
\hline
\end{tabular}




\begin{tabular}{|c|c|c|c|}
\hline \multirow[t]{3}{*}{ Convenience } & Other people need it more & 7 & $\begin{array}{l}\text { "More at-risk people need it first" } \\
\text { "It should be delivered to needy first, I'll have to wait for offer" } \\
\text { "I'm fit and healthy that there are more vulnerable people who need } \\
\text { it before I do" }\end{array}$ \\
\hline & Inconvenience & 1 & "Inconvenient" \\
\hline & Freedom of choice & 1 & $\begin{array}{l}\text { "If it were a requirement by law, I would not want it, freedom of } \\
\text { choice is important" }\end{array}$ \\
\hline
\end{tabular}


Table 1b: Common reasons for vaccine acceptance: survey findings

\begin{tabular}{|c|c|c|}
\hline Themes & Count & Example of responses \\
\hline Self-protection & 208 & $\begin{array}{l}\text { "To protect me from getting COVID-19" } \\
\text { "I'm in a vulnerable group" } \\
\text { "It would make mee feel safer" }\end{array}$ \\
\hline $\begin{array}{l}\text { Protect specific others (e.g., family, friends, } \\
\text { colleagues etc.) }\end{array}$ & 57 & $\begin{array}{l}\text { "I want myself, my loved ones, and my community to be safe" } \\
\text { "Don't want to catch the virus and give it to my family" } \\
\text { "Want to protect myself and my family" }\end{array}$ \\
\hline $\begin{array}{l}\text { Protect the population/non-specific others } \\
\text { and control the virus }\end{array}$ & 139 & $\begin{array}{l}\text { "Vaccines are important not just to protect ourselves but others and essential to } \\
\text { stop the spread" }\end{array}$ \\
\hline
\end{tabular}




\begin{tabular}{|c|c|c|}
\hline & & $\begin{array}{l}\text { "To protect the vulnerable who can't take the vaccine" } \\
\text { "It may save many lives" } \\
\text { "The need for herd immunity via vaccine is very important and there needs to be } \\
\text { a critical mass of people taking this up" }\end{array}$ \\
\hline Confidence in SARS-Cov-2 vaccine & 87 & $\begin{array}{l}\text { "It has been clinically tested and I trust the process" } \\
\text { "I don't believe a vaccine once approved would be unsafe" } \\
\text { "It has shown to be effective" }\end{array}$ \\
\hline $\begin{array}{l}\text { Hope to end the pandemic/ wish for normal } \\
\text { life }\end{array}$ & 185 & $\begin{array}{l}\text { "I want to be able to resume my life" } \\
\text { "So that life can get back to normal" }\end{array}$ \\
\hline
\end{tabular}




\begin{tabular}{|c|c|c|}
\hline & & $\begin{array}{l}\text { "I just want to be able to hug my daughters" } \\
\text { "Truly get on top of this virus and get all our lives and the economy and health } \\
\text { service back in action" }\end{array}$ \\
\hline Civil duty/Requirement & 21 & $\begin{array}{l}\text { "Everyone who can, should have it. Vaccines are our best chance of eradicating } \\
\text { it" } \\
\text { "It's my social responsibility" } \\
\text { "I would feel it was my duty, to help to protect other people" }\end{array}$ \\
\hline $\begin{array}{l}\text { Non-specific pro-vaccine/pro-science } \\
\text { statement }\end{array}$ & 49 & $\begin{array}{l}\text { "I believe in science" } \\
\text { "Vaccine works" }\end{array}$ \\
\hline
\end{tabular}


"I would take any vaccine at this point"

"Can't think of a good reason why not to take it" 
medRxiv preprint doi: https://doi.org/10.1101/2021.03.24.21254124; this version posted April 22, 2021. The copyright holder for this preprint (which was not certified by peer review) is the author/funder, who has granted medRxiv a license to display the preprint in perpetuity.

All rights reserved. No reuse allowed without permission.

\subsection{Rapid Systematic Literature Review}

To identify additional themes/reasons for COVID-19 vaccine hesitancy that may have not been captured in our survey, a rapid systematic literature review was conducted. Four electronic databases (Medline, PsychInfo, Medrxiv, PsyAxiv) were searched to identify peerreviewed journal articles and pre-prints which examined reasons for COVID-19 vaccine hesitancy dated between 01/01/2020 and 03/12/2020: using the following search terms: (COVID-19 vaccine hesitancy) OR ((COVID-19) AND (Vaccine hesitancy)). One researcher (RJ) conducted abstract and full-text screening to determine eligibility and a second crosschecked all eligibility decisions (KA).

Following title and abstract screening, 49 articles remained for full-text screening, with 10 ultimately deemed suitable for inclusion summarised in table 2 [15-24]. The primary reason for excluding articles at the full-text screening stage were that many studies looked at vaccine intention only, not reasons for vaccine hesitancy (see Figure 1). Three of the studies were conducted in the United States, and two in the United Kingdom. The remaining 5 studies were conducted in Nigeria, Mainland China, Hong-Kong, France and Malta respectively. Six studies identified reasons for vaccine hesitancy based on survey questions where a preselected list of potential reasons were given. Three studies coded free-text responses to survey questions and one study analysed participant interviews. Six of the studies collected data from general population sample, three collected data from healthcare workers and one did both.

The most common themes identified in this review mirrored those identified in our survey. However, the following additional themes were identified: (1) vaccine scepticism; (2) cost of vaccines; (3) concerns relating to vaccine contents; (4) timing of vaccination in relation to the state of the pandemic and (5) concern that the vaccine might result in COVID-19 disease (see table 2). 
medRxiv preprint doi: https://doi.org/10.1101/2021.03.24.21254124; this version posted April 22, 2021. The copyright holder for this preprint (which was not certified by peer review) is the author/funder, who has granted medRxiv a license to display the preprint in perpetuity.

All rights reserved. No reuse allowed without permission.

Figure 1 PRISMA summary of search procedure
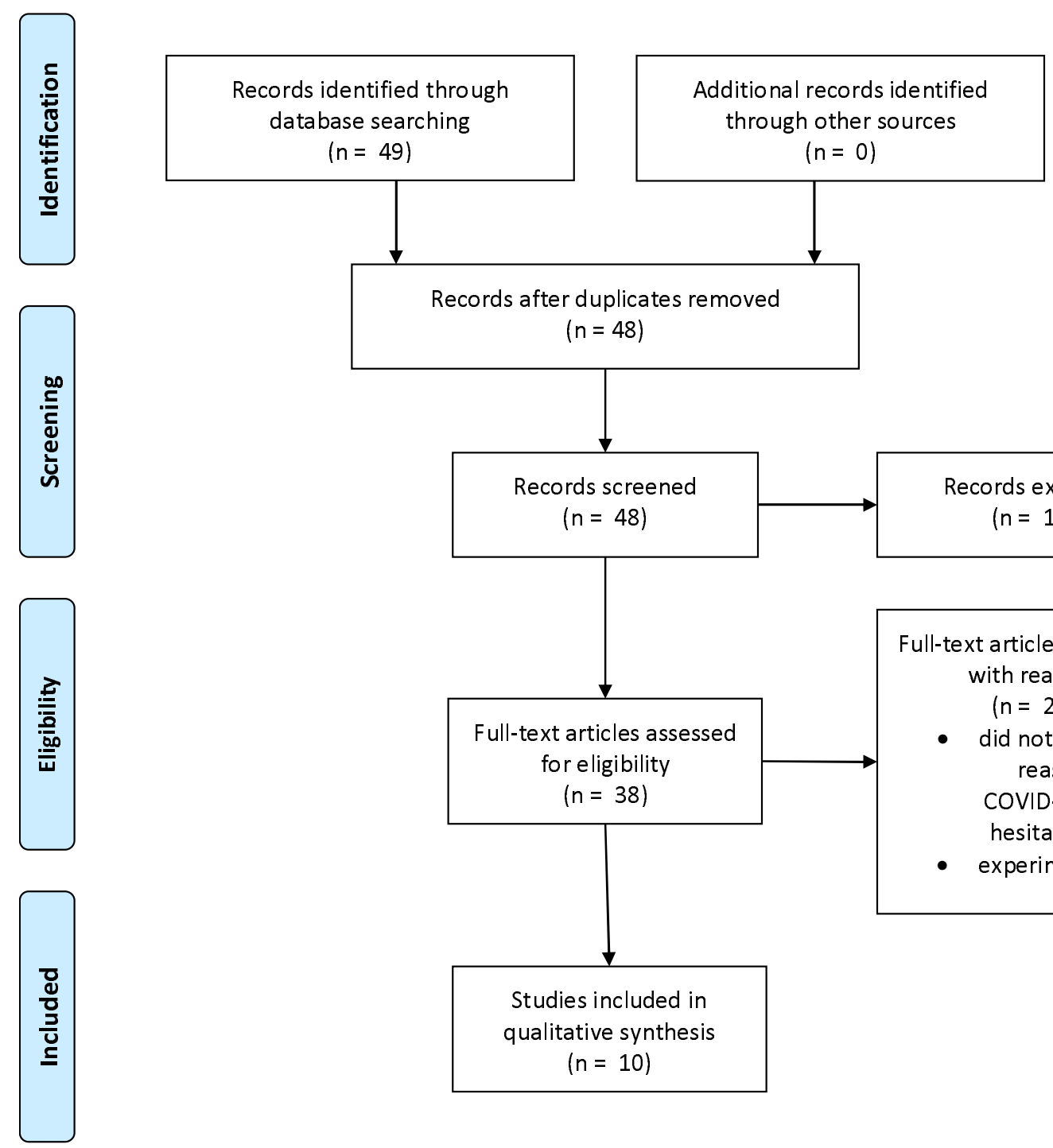

Records after duplicates removed $(n=48)$

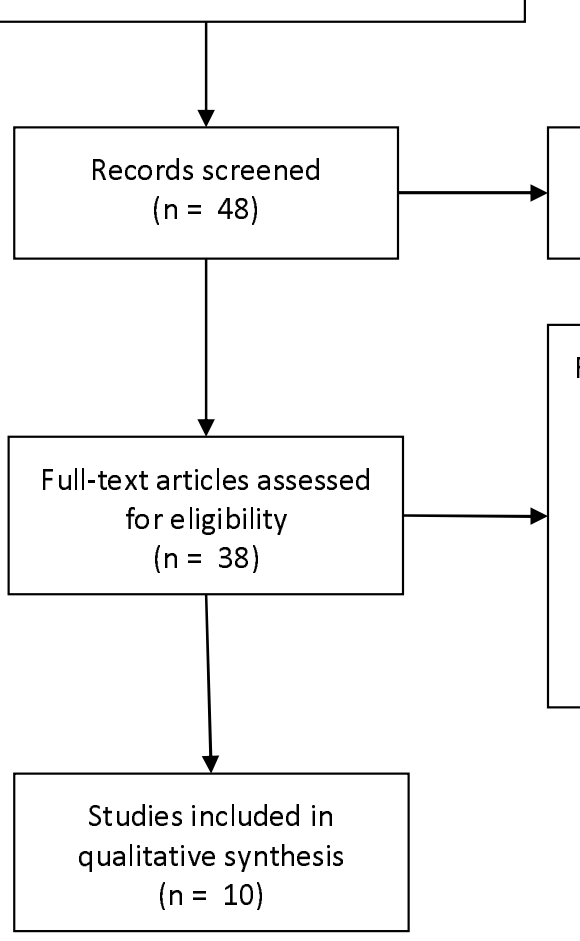

Records excluded $(n=10)$

Full-text articles excluded, with reasons

$(n=28)$

- did not investigate reasons for COVID-19 vaccine hesitancy $(n=27)$

- experiment $(n=1)$ 
Table 2 Summary of studies included in rapid literature review

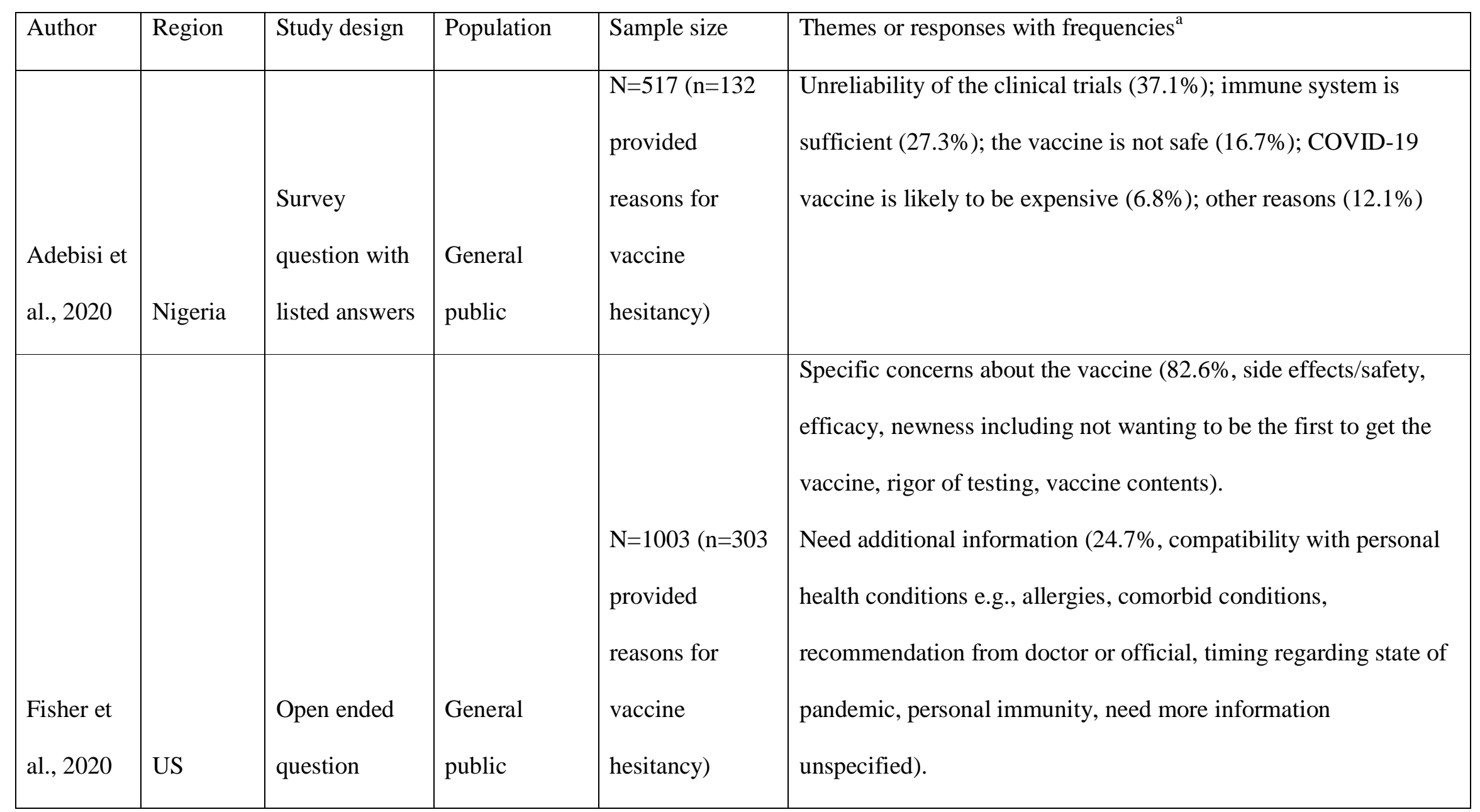




\begin{tabular}{|c|c|c|c|c|c|}
\hline & & & & & $\begin{array}{l}\text { Anti-vaccine attitudes, beliefs, and emotions ( } 76.6 \% \text {, don't need } \\
\text { the vaccine e.g., not at risk, religious beliefs, don't believe the } \\
\text { vaccine will work informed by reference to other bad vaccine } \\
\text { experiences/flu shots not working/vaccine won't work against } \\
\text { mutation organism, general statements about not getting vaccines, } \\
\text { not comfortable with vaccines, fear about vaccines, } \\
\text { misconceptions/incorrect information about vaccines). } \\
\text { Lack of trust in vaccines, government and Centers for Disease } \\
\text { Control and Prevention (CDC), pharmaceutical companies, } \\
\text { vaccine development or testing process, reference to specific } \\
\text { conspiracy theories, distrust unspecified ( } 45.2 \%) \text {. } \\
\text { Other (9.8\%, altruism i.e., wanting higher risk individuals to get } \\
\text { first, cost, dislike of needles). }\end{array}$ \\
\hline $\begin{array}{l}\text { Fu et al., } \\
2020\end{array}$ & $\begin{array}{l}\text { Mainland } \\
\text { China }\end{array}$ & $\begin{array}{l}\text { Survey } \\
\text { question with }\end{array}$ & $\begin{array}{l}\text { Healthcare } \\
\text { workers and }\end{array}$ & $\begin{array}{l}\mathrm{N}=541(\mathrm{n}=445 \\
\text { provided }\end{array}$ & $\begin{array}{l}\text { Concerns about vaccine safety: newness of vaccine, effectiveness } \\
\text { of the vaccine. Cost of the vaccine }\end{array}$ \\
\hline
\end{tabular}




\begin{tabular}{|c|c|c|c|c|c|}
\hline & & listed answers & $\begin{array}{l}\text { general } \\
\text { population }\end{array}$ & $\begin{array}{l}\text { responses in } \\
\text { relation to } \\
\text { vaccine } \\
\text { hesitancy) }\end{array}$ & \\
\hline $\begin{array}{l}\text { Grech et } \\
\text { al., } 2020\end{array}$ & Malta & $\begin{array}{l}\text { Survey } \\
\text { question with }\end{array}$ & $\begin{array}{l}\text { Family } \\
\text { physicians }\end{array}$ & $\begin{array}{l}\mathrm{N}=350(\mathrm{n}=123 \\
\text { provided }\end{array}$ & $\begin{array}{l}\text { The majority of the COVID-19 vaccine related concern were long } \\
\text { term side effects and insufficient knowledge about the vaccine. }\end{array}$ \\
\hline
\end{tabular}




\begin{tabular}{|c|c|c|c|c|c|}
\hline & & listed answers & and trainees & $\begin{array}{l}\text { responses in } \\
\text { relation to } \\
\text { vaccine } \\
\text { hesitancy) }\end{array}$ & $\begin{array}{l}\text { Other concerns included: short term side effects (e.g., fever), } \\
\text { vaccine effectiveness and general anti-vaccine attitudes. }\end{array}$ \\
\hline $\begin{array}{l}\text { Hacquin } \\
\text { et al., } \\
2020\end{array}$ & France & Interviews & $\begin{array}{l}\text { General } \\
\text { public }\end{array}$ & $\begin{array}{l}\mathrm{N}=5028 \\
(\mathrm{n}=1004 \\
\text { provided } \\
\text { responses in } \\
\text { relation to } \\
\text { vaccine } \\
\text { hesitancy) }\end{array}$ & $\begin{array}{l}\text { General opposition to vaccines; concerns that the vaccine would } \\
\text { not be effective; not personally required (don't need to get } \\
\text { vaccinated); lack of trust in government and pharmaceutical } \\
\text { industries. }\end{array}$ \\
\hline $\begin{array}{l}\text { Kwok et } \\
\text { al., } 2020\end{array}$ & $\begin{array}{l}\text { Hong } \\
\text { Kong }\end{array}$ & $\begin{array}{l}\text { Survey } \\
\text { question with } \\
\text { listed answers } \\
\text { from a scale }\end{array}$ & Nurses & $\begin{array}{l}\mathrm{N}=1205 \\
\text { provided } \\
\text { responses in } \\
\text { relation to }\end{array}$ & $\begin{array}{l}\text { Confidence in safety; effectiveness; and trust in other authorities. } \\
\text { Complacency regarding whether the disease is common; that the } \\
\text { immune system is sufficient to fight off the disease and the disease } \\
\text { is not severe. } \\
\text { Constraints to getting vaccinated such as everyday stress; }\end{array}$ \\
\hline
\end{tabular}




\begin{tabular}{|c|c|c|c|c|c|}
\hline & & & & $\begin{array}{l}\text { vaccine } \\
\text { hesitancy) }\end{array}$ & $\begin{array}{l}\text { inconvenience; visiting the doctors; discomfort. } \\
\text { Calculations involving weighing up benefits and risks; needing to } \\
\text { closely consider whether it is personally useful; needing to } \\
\text { understand more about vaccines and vaccination. } \\
\text { Collective responsibility including, it not being necessary to get } \\
\text { the vaccine when everyone is vaccinated; getting vaccinated can } \\
\text { enable an individual to protect people with weaker immune } \\
\text { systems; vaccination is a collective action to prevent the spread of } \\
\text { diseases. }\end{array}$ \\
\hline $\begin{array}{l}\text { Pogue et } \\
\text { al., } 2020\end{array}$ & US & $\begin{array}{l}\text { Survey } \\
\text { question with } \\
\text { listed answers }\end{array}$ & $\begin{array}{l}\text { General } \\
\text { public }\end{array}$ & $\begin{array}{l}\mathrm{N}=316(33.5 \% \\
\text { provided } \\
\text { responses in } \\
\text { relation to } \\
\text { vaccine } \\
\text { hesitancy) }\end{array}$ & $\begin{array}{l}\text { Concerns about vaccine safety }(45.5 \%) \text {; lack of trust in the source } \\
\text { that encouraged them to receive the vaccine }(13.5 \%) \text {; other e.g., } \\
\text { need more testing on the vaccines }(15.5 \%) \text {. }\end{array}$ \\
\hline
\end{tabular}




\begin{tabular}{|c|c|c|c|c|c|}
\hline $\begin{array}{l}\text { Sherman } \\
\text { et al., } \\
2020\end{array}$ & UK & $\begin{array}{l}\text { Survey } \\
\text { question with } \\
\text { listed answers } \\
\text { from a scale }\end{array}$ & $\begin{array}{l}\text { General } \\
\text { public }\end{array}$ & $\begin{array}{l}\mathrm{N}=1500 \\
\text { ( } \mathrm{n}=1448 \\
\text { provided } \\
\text { responses in } \\
\text { relation to } \\
\text { vaccine } \\
\text { hesitancy) }\end{array}$ & $\begin{array}{l}\text { Concerns about safety and side effects of the vaccine; newness of } \\
\text { the vaccine; needing sufficient information to make an informed } \\
\text { decision; afraid of needles; not at risk of serious illness from } \\
\text { covid; trust in manufacturers/government/health care } \\
\text { professionals; }\end{array}$ \\
\hline $\begin{array}{l}\text { Williams } \\
\text { et al., } \\
2020\end{array}$ & UK & $\begin{array}{l}\text { Free text } \\
\text { question }\end{array}$ & $\begin{array}{l}\text { General } \\
\text { public }\end{array}$ & $\begin{array}{l}\mathrm{N}=527(\mathrm{n}=158 \\
\text { provided } \\
\text { reasons for } \\
\text { vaccine } \\
\text { hesitancy) }\end{array}$ & $\begin{array}{l}\text { Concerns about vaccine safety (100\%) centred on the newness of } \\
\text { the vaccine and its safety (e.g., long-term effect, side effects) and } \\
\text { effectiveness. }\end{array}$ \\
\hline
\end{tabular}

${ }^{a}$ Themes or responses were based on participants who provided information on vaccine hesitancy. 
medRxiv preprint doi: https://doi.org/10.1101/2021.03.24.21254124; this version posted April 22, 2021. The copyright holder for this preprint

(which was not certified by peer review) is the author/funder, who has granted medRxiv a license to display the preprint in perpetuity.

All rights reserved. No reuse allowed without permission.

\subsection{Additional insights from Public and Patient Involvement (PPI)}

To ensure we captured the views of ethnic minority groups on COVID-19 vaccines, we also consulted PPI findings available through the University Hospital Southampton NHS Foundation Trust PPI team regarding the acceptability of vaccines. Several PPI meetings were held on this broad area between July-October 2020, including meetings that specifically sought the views of Black and Minority Ethnic (BAME) individuals.

The feedback from all the consultation meetings was reviewed and was found to reveal considerable overlap in the vaccine concerns identified in these meetings, with those identified as part of our survey and literature review. The only additional concerns related to whether vaccines had been tested on people from different ethnic groups and issues of trust in the medical and scientific communities. These issues were, therefore, prioritised for inclusion in our intervention.

\subsection{Synthesising findings from Stage 1 to identify most common reasons for vaccine}

\section{hesitancy.}

The evidence emerging from the survey, rapid literature review and PPI findings was then triangulated through discussion between the behavioural scientists contributing to this stage of the work. The aim of these discussions was to identify the most common COVID-19 vaccine concerns. This was based in part on the frequency with which concerns were identified in the survey, review, and PPI findings; ensuring that all three domains of the WHO 3C model were represented and that any unique perspectives raised by ethnic minority participants were also captured.

This led to the identification of nine core COVID-19 vaccine concerns. In keeping with the most frequently cited concerns being related to 'confidence', 5/9 concerns related to 'confidence' (i.e., generalisability of evidence on vaccine safety and effectiveness to diverse 
populations; side-effects; rapid nature of vaccine development; clinical effectiveness and vaccine scepticism). Two out of ten concerns related to 'complacency' (i.e., low perceived risk of COVID-19 and belief in ability to fight off the infection naturally). A further two concerns related to 'convenience' (i.e., perceived lack of knowledge about COVID-19 vaccine and altruistic beliefs regarding others having a greater need). A tenth concern was subsequently added when the UK government decided to alter the dosing schedule from $3 / 4$ weeks to up to 12 weeks between the two doses recommended for the Astra Zeneca and Pfizer vaccines. In keeping with the WHO 3C model, this latter issue also related to the issue of 'confidence'.

\section{Stage 2: Synthesising the evidence-based views of independent experts.}

Following the identification of 10 core vaccine concerns (Table 3) we sought to gather evidence-based responses to these concerns. This was achieved through semi-structured interviews with six academic and clinical experts from the fields of public health, general medicine, respiratory medicine and immunology with particular expertise in COVID-19 and/or COVID-19 vaccines. Each expert was presented with the list of 10 concerns and asked to provide an evidence-based response to each concern based on their knowledge of the scientific literature at that time. Interviews with experts were subjected to rapid thematic and content analysis after each interview and interviews continued until saturation in responses was achieved (i.e., no new responses emerged) [25].

The expert responses demonstrated significant thematic overlap and consistency. Table 3 summarises the areas of evidence cited by experts in response to each concern. 
Table 3: Expert responses to 10 most common reasons for vaccine hesitancy

\begin{tabular}{|c|c|}
\hline Concern & Key responses \\
\hline $\begin{array}{l}\text { "I don't know if the } \\
\text { vaccines have been tested } \\
\text { on people like me: } \\
\text { • By age, ethnicity, } \\
\text { and comorbid health } \\
\text { condition" }\end{array}$ & $\begin{array}{l}\text { - The vaccines have been trialled in } 10 \text { s of } 1000 \text { s of } \\
\text { people across many countries and ethnicities } \\
\text { - No discernible difference in response to the vaccine } \\
\text { across ethnic groups or age groups } \\
\text { - Researchers included individuals with common } \\
\text { chronic health conditions in the trials to ensure any } \\
\text { risks to this population were identified } \\
\text { Pregnant and breastfeeding women were not } \\
\text { included in the trials }\end{array}$ \\
\hline $\begin{array}{l}\text { "I don't think we know } \\
\text { enough about the side- } \\
\text { effects of the vaccines" }\end{array}$ & $\begin{array}{l}\text { - All COVID-19 vaccines have undergone very robust } \\
\text { testing, including pauses to trials to explore whether } \\
\text { adverse events or allergic reactions were as a result } \\
\text { of the vaccine itself } \\
\text { - These vaccines follow the same trial protocols for } \\
\text { reporting adverse events to the medical advisory } \\
\text { boards that all other vaccines must follow } \\
\text { All vaccines come with the chance of immediate } \\
\text { side effects, such as a sore arm, fever etc. This } \\
\text { shows the immune system has responded to the } \\
\text { vaccine } \\
\text { Short term side effects are similar to all other } \\
\text { vaccines }\end{array}$ \\
\hline
\end{tabular}




\begin{tabular}{|c|c|}
\hline & $\begin{array}{l}\text { - Although there is less safety data available, MRNA } \\
\text { vaccines have been studied for years }\end{array}$ \\
\hline $\begin{array}{l}\text { "I think the whole process } \\
\text { has been rushed" }\end{array}$ & $\begin{array}{l}\text { - The vaccines have followed the same development } \\
\text { criteria that all vaccines must undergo } \\
\text { - Many other vaccines are developed in a similar time } \\
\text { frame, such as the flu vaccine. } \\
\text { The difference in timeframes has resulted in the } \\
\text { concerted channelling of funds into the development } \\
\text { of these vaccines, with governments, manufacturers, } \\
\text { and scientific bodies providing substantial and rapid } \\
\text { funding, expediting the researchers' ability to test } \\
\text { the vaccines } \\
\text { - Some vaccines, such as the Oxford Astra-Zeneca } \\
\text { vaccine, were developed quickly because the } \\
\text { genetic make-up of the virus much more quickly } \\
\text { researchers utilised an existing vaccine formula and } \\
\text { inserted in an inert form of the COVID-19 virus. } \\
\text { the regulators prioritised reviewing the trial data }\end{array}$ \\
\hline $\begin{array}{l}\text { "I don't know if they will } \\
\text { work" }\end{array}$ & $\begin{array}{l}\text { - The data suggests short-term protection of at least } 3 \\
\text { months } \\
\text { - Pfizer vaccines is highly effective in the short term - }\end{array}$ \\
\hline
\end{tabular}




\begin{tabular}{|c|c|}
\hline & $\begin{array}{l}\text { approximately } 95 \% \\
\text { - Oxford-AstraZeneca rates varied, but were } \\
\text { approximately } 70 \% \text { effective } \\
\text { - However, long-term data has yet to be reported } \\
\text { - We don't know yet if the vaccines prevent } \\
\text { transmission }\end{array}$ \\
\hline $\begin{array}{l}\text { "I don't think I am at risk of } \\
\text { getting COVID-19" }\end{array}$ & $\begin{array}{l}\text { Whilst many people experience mild symptoms, } \\
\text { COVID-19 is unpredictable; we are not able to } \\
\text { predict who will be adversely affected. } \\
\text { - Although COVID-19 affects older people most } \\
\text { severely, a significant proportion of those } \\
\text { hospitalised are under the age of } 60 \text {. } \\
\text { We know that you can contract COVID-19 more } \\
\text { than once and are unsure how long any immunity to } \\
\text { the virus lasts after exposure. } \\
\text { The vaccines offer protection against the virus and } \\
\text { prevent the risk of experiencing a severe form of the } \\
\text { disease. } \\
\text { Receiving a vaccine could prevent you from } \\
\text { requiring hospitalisation. } \\
\text { vaccination reduces the volume of the population } \\
\text { who can contract and spread the virus, reducing the } \\
\text { - }\end{array}$ \\
\hline "I think my body can fight & - Younger individuals are less likely to experience \\
\hline
\end{tabular}




\begin{tabular}{|c|c|}
\hline the virus on its own" & $\begin{array}{l}\text { severe COVID-19, however there is still the risk of } \\
\text { this happening. } \\
\text { - It is also possible to get re-infected with the virus, } \\
\text { although evidence suggests the reinfection results in } \\
\text { less severe illness. } \\
\text { The immune system can exhibit extreme reactions to } \\
\text { the COVID-19 virus, but it is very unlikely to react } \\
\text { in such a way to the vaccines. } \\
\text { Reducing your risk of contracting and therefore } \\
\text { spreading COVID-19 helps to protect others. } \\
\text { Reducing your risk of contracting COVID-19 also } \\
\text { means you are much less likely to need to self- } \\
\text { isolate. }\end{array}$ \\
\hline $\begin{array}{l}\text { "I just don't know enough } \\
\text { about it: } \\
\text { Safety and effectiveness } \\
\text { concerns", }\end{array}$ & $\begin{array}{l}\text { - The vaccines all significantly reduce the risk of } \\
\text { contracting severe COVID-19. } \\
\text { - Effectiveness has been shown in individuals of all } \\
\text { ages, ethnic backgrounds, and with other health } \\
\text { conditions. } \\
\text { No serious side effects have been reported; } \\
\text { participants in the early trials have now been } \\
\text { monitored for almost } 12 \text { months. } \\
\text { The MHRA have been monitoring the vaccines' } \\
\text { safety extremely carefully, as they do with all other } \\
\text { vaccines. }\end{array}$ \\
\hline
\end{tabular}




\begin{tabular}{|c|c|}
\hline $\begin{array}{l}\text { "Other people need it more } \\
\text { than me" }\end{array}$ & $\begin{array}{l}\text { The Joint Committee for Vaccines and } \\
\text { Immunisations (JCVI) has identified a priority list } \\
\text { for vaccine dissemination. } \\
\text { - If someone is offered a vaccine, it means they have } \\
\text { been identified as being in a priority group. } \\
\text { Receiving a vaccine does not detract from someone } \\
\text { else receiving a vaccine. }\end{array}$ \\
\hline $\begin{array}{l}\text { "I don't believe in vaccines: } \\
\text { Safety and effectiveness } \\
\text { concerns" }\end{array}$ & $\begin{array}{l}\text { Vaccines save millions of lives every year and there } \\
\text { is no evidence for adverse effects of the COVID-19 } \\
\text { vaccines. }\end{array}$ \\
\hline $\begin{array}{l}\text { "I'm worried I would have } \\
\text { to wait } 12 \text { weeks before I } \\
\text { get my second dose" }\end{array}$ & $\begin{array}{l}\text { This decision was taken because it allows twice as } \\
\text { many people to get some protection against the } \\
\text { virus, offering the greatest opportunity to save lives. } \\
\text { The first vaccination offers short term protection, } \\
\text { whilst the second booster dose provides longer term } \\
\text { protection. } \\
\text { Delaying the second dose from } 3 \text { to } 12 \text { weeks also } \\
\text { gives the immune system longer to develop } \\
\text { immunity. } \\
\text { In the Oxford-AstraZeneca vaccine trials, a longer } \\
\text { gap between doses offered better protection. }\end{array}$ \\
\hline
\end{tabular}

\section{Stage 3: Developing therapeutic dialogues to address common vaccine hesitancy} concerns. 
Our approach to developing the intervention was predicated on two main observations of the existing evidence. First that psychoeducation alone (i.e. provision of information gathered in Stage 2) is unlikely to be an effective way to address COVID-19 vaccine concerns. Second that a central pillar of our approach should be to acknowledge and engage with individuals' concerns in a supportive context. To achieve this, we sought to develop 'therapeutic dialogues' based on the communication principles of motivational interviewing (MI) including:

- Expressing empathy: cultivating an empathic space with which to explore hesitancy

- Developing discrepancy: identifying areas in which a person's actions are misaligned with their personal values and goals

- Embracing resistance: working collaboratively with an individual to foster change and recognising when that resistance and motivation are intricately tied

- Supporting self-efficacy: enhancing confidence that an individual can embark on change[26].

MI was considered an appropriate approach because individuals who are vaccine hesitant are, by definition, not ready to, or ambivalent about, changing their cognitions and behaviour and MI is known to be effective in such contexts.[27,28] Thus, for each of the most common vaccine concerns identified in Stage 1 we developed a therapeutic dialogue which would both impart information relevant to the individual concern, but do so using the communication principles of MI with a view to facilitating cognitive and, in turn, behaviour change i.e., reduce hesitancy and improve vaccine uptake.

Development of the therapeutic dialogues occurred through several expert workshops with behavioural scientists with expertise in MI, therapeutic interventions, digital interventions, behaviour change and COVID-19. First, key themes identified in the expert interviews (Stage 2) were discussed and translated into conversational language. The investigators chose a 
conversational approach to align with the online delivery format and to ensure inclusivity for all reading/English levels (see stage 4 below). Second, the dialogues were reviewed to identify points at which MI techniques could be integrated throughout. This process drew on contributors' experience in behaviour change research and adopted the approach proposed by Rollnick and colleagues [26]. This included expressing empathy through use of accepting and non-judgemental language. Developing discrepancy by simultaneously providing information related to the concern, and presenting a rationale for vaccine uptake. The latter were derived from survey respondents willing to accept a COVID-19 vaccine (see Table 1b) and sought to develop a discrepancy between the individual's cause for concern and their wider personal values and goals. Embracing resistance by acknowledging that their concerns are shared by others and are legitimate and supporting self-efficacy by reinforcing the individual's personal agency in making their decision to accept a vaccine or not. See Table 4 for illustrative examples of how MI principles were embedded within the therapeutic dialogues.

Table 4. Exemplars of how MI principles were included within the therapeutic dialogues

\begin{tabular}{|c|c|c|}
\hline Concern & $\begin{array}{l}\text { Motivational interviewing } \\
\text { concept }\end{array}$ & $\begin{array}{l}\text { Concept example utilised in } \\
\text { the dialogue }\end{array}$ \\
\hline $\begin{array}{l}\text { "I don't know if the vaccines } \\
\text { have been tested on people } \\
\text { like me" }\end{array}$ & $\begin{array}{l}\text { Expressing empathy: } \\
\text { Including reflective } \\
\text { listening to concerns } \\
\text { and integration of } \\
\text { follow up questions } \\
\text { to engage user }\end{array}$ & $\begin{array}{l}\text { These are brand new } \\
\text { vaccines and it is completely } \\
\text { understandable that you } \\
\text { would ask about their safety }\end{array}$ \\
\hline "I don't believe I am at risk & Developing discrepancy: & So when you choose to have \\
\hline
\end{tabular}




\begin{tabular}{|c|c|c|}
\hline of getting COVID-19" & $\begin{array}{l}\text { Identifying potential } \\
\text { areas of conflict } \\
\text { between vaccine } \\
\text { hesitancy and } \\
\text { personal values }\end{array}$ & $\begin{array}{l}\text { a vaccination you are also } \\
\text { choosing to protect others, } \\
\text { to take the pressure off the } \\
\text { NHS, and helping us all get } \\
\text { back to normal. }\end{array}$ \\
\hline $\begin{array}{l}\text { "I don't think we know } \\
\text { enough about the side- } \\
\text { effects of the vaccines" }\end{array}$ & $\begin{array}{l}\text { Embracing resistance: } \\
\text { Recognising } \\
\text { resistance and } \\
\text { helping to move } \\
\text { forward } \\
\text { collaboratively }\end{array}$ & $\begin{array}{l}\text { And you are not alone in } \\
\text { wondering about this. } \\
\text { Scientists, doctors, the } \\
\text { independent regulator who } \\
\text { decide on which medicines } \\
\text { can be offered to the public } \\
\text { (the Medicines and } \\
\text { Healthcare Products } \\
\text { Regulatory Agency) all want } \\
\text { to know how well the } \\
\text { vaccines work. }\end{array}$ \\
\hline $\begin{array}{l}\text { "I don't know if the vaccines } \\
\text { have been tested on people } \\
\text { like me" }\end{array}$ & $\begin{array}{l}\text { Supporting self-efficacy } \\
\text { Enhancing } \\
\text { confidence to make } \\
\text { an informed decision } \\
\text { about whether to } \\
\text { receive a vaccine }\end{array}$ & $\begin{array}{l}\text { We hope we have been able } \\
\text { to help with your concerns } \\
\text { about the safety of the } \\
\text { vaccines. To sum up, they } \\
\text { have all been monitored } \\
\text { very closely to find side } \\
\text { effects. But if you did } \\
\text { experience a side effect it is } \\
\text { most likely to be very minor }\end{array}$ \\
\hline
\end{tabular}




\begin{tabular}{|l|l|l|}
\hline & & $\begin{array}{l}\text { and much less severe than } \\
\text { catching COVID-19. }\end{array}$ \\
\hline
\end{tabular}

Finally, we hosted a PPI workshop to discuss the resulting dialogues. The group, while small $(n=4)$, included two adults less than 30 years (two greater than 50 years); three women and one man and all reported an interest in vaccine hesitancy and had some experiences of it in friends and family. The feedback obtained through this workshop fostered changes to their readability, along with expansion of the information conveyed and greater consideration of specific groups within the population (i.e. those who have allergies or specific religious and cultural needs). No additional vaccine concerns were identified by the group.

\section{Stage 4: The digital intervention.}

The script from each of the 10 therapeutic dialogues provided the architecture for our digital, web-based, vaccine hesitancy intervention. This intervention has been built in the form of a conversational interface through which individuals identify the issue that most closely underpins their reason for being hesitant, (from the issues stated above e.g., concerns about side effects). This identification triggers a therapeutic dialogue relevant to the selected concern, with opportunities for the individual to further explore the content as they progress through the dialogue as well as to access responses to more than just their initial concern. Once developed, the digital intervention was piloted with 18 members of the public (nine male / nine female) who had no previous experience with the dialogues. Participant feedback on the user interface, accessibility, and general presentation led to a final iteration of the intervention, which can be viewed here www.covidvaxfacts.info ${ }^{1}$ 


\section{Discussion}

The development of safe and effective vaccines against SARS CoV-2, while necessary, will not be sufficient to contain COVID-19 unless we also achieve high vaccine uptake. We have described here the rapid development of an evidence-based digital intervention which draws on the communication principles of MI and is in keeping with many of the recommendations made in a recent review of approaches to increasing vaccine uptake e.g., focus on the concerns of the population.[29] Our aim is to provide the end-user with an intervention which is individualised to their specific concerns, acknowledges the legitimacy of these concerns, provides up to date information related to these concerns whilst also providing an accepting non-judgemental context in which they can explore their reasons for hesitancy. The textbased content and digital format mean it can be readily scaled-up for wider dissemination and rapidly modified for implementation in different languages and to respond to changing information.

Although this intervention, like much else to do with COVID-19, has been developed at pace we think the process highlights some potential issues regarding intervention development worthy of discussion. First, the development of our digital, behavioural intervention followed a fairly conventional path as outlined in the Medical Research Council's (MRC) best practice guidance. This involved evaluating the evidence base and theory as well as incorporating the views of target users [30]. This was possible partly because we had timely access to PPI findings available through the University Hospital Southampton NHS Foundation Trust regarding the acceptability of vaccines, allowing rapid comparison of the PPI findings with the concerns identified through our existing survey data and literature review.

A critical step in digital intervention development is optimisation of intervention content, since digital intervention content cannot be adjusted 'in the moment', like in a practitioner 
delivered intervention. We were able to conduct optimisation work with PPI, albeit with a smaller sample $(\mathrm{N}=4)$ than might usually be employed in digital intervention development. Computer science methodology states that during intervention optimisation around $80 \%$ of views can be captured with five target users and we were close to this threshold [31]. However, best practice guidance from digital health psychology suggests including larger, diverse samples is important to ensure views of people from different backgrounds are considered [30]. Despite having a smaller sample, our optimisation with PPI did help us to improve the persuasiveness and accessibility of the key messages within the intervention. It is possible that we may have found other important ways of optimising our content by including a larger, more diverse group of PPI at this stage. However, it is important to note that this intervention is quite simple, it targets only one behaviour, draws on a very well-established behavioural technique which guided content design (MI), and it addressed barriers that were thoroughly identified using existing evidence in the intervention planning stage. Therefore, in this particular context, it is possible that sufficient optimisation was achieved with a smaller sample.

The MRC highlights the importance of making use of existing data and evidence wherever possible. In this work, we were able to benefit from data collected as part of another study[14] where we were able to identify specific concerns related to vaccine hesitancy. We also drew on evidence kindly shared with us by others. This allowed acceleration of the intervention development and improved the economic efficiency of research.

In view of the urgency of the public health issue we conducted a rapid review. Indeed, COVID-19 has most likely led to an unprecedented number of rapid reviews, as the scientific community have clamoured to understand the available evidence as quickly as possible. Although, it is clear that rapid reviews take many forms (e.g., limited by language, dates, databases etc.), they do vary in the quality of their reporting and the methodological shortcuts 
they take.[32] The implications of these inconsistencies for the quality and validity of these reviews is, however, unclear as there is thus far limited evidence comparing the results of different review approaches. The provision of such evidence in future research would undoubtedly inform the contexts in which it is appropriate to conduct rapid reviews, and the methods that should be employed. Such guidance now exists for scoping reviews[33] and would appear to be in development for rapid reviews by the Equator network.[34]

\section{Conclusion}

In summary, for COVID-19 vaccines to achieve their full public health potential, the public need to be willing to be vaccinated. Recent data suggest this cannot be assumed. We have reported here on the development of a scalable digital intervention which seeks to address the concerns of individuals who are vaccine hesitant with a view to enhancing their confidence in COVID-19 vaccines and, in turn their uptake. The effects of the intervention on these outcomes will be the subject of future work.

\section{Footnotes}

${ }^{1}$ Web URL is not currently active but will be active by the time of publication

\section{Funding}

This work was supported by the School of Primary Care Research [Grant Number 434].

\section{Conflicts of Interest}

The authors declare that they have no known competing financial interests or personal relationships that could have appeared to influence the work reported in this paper. This report is independent research supported by the National Institute for Health Research ARC 
Wessex. The views expressed in this publication are those of the author(s) and not necessarily those of the National Institute for Health Research or the Department of Health and Social Care.

\section{Authorship contribution statement}

$\mathrm{HK}, \mathrm{KV}, \mathrm{KB}, \mathrm{KB}, \mathrm{TC}$ : conceptualisation, data analysis, writing original draft, reviewing and editing. RJ, KA: Conducted rapid literature review, writing of original draft, reviewing and editing. WSL, JRM, LD: conceptualisation, expert contributions through qualitative interviews, reviewing and editing. TA, JB, CB, RB, TMK: reviewing and editing.

\section{Acknowledgements}

We would like to thank Dr Lucy Fairclough (University of Nottingham), Dr Simon Royal (University of Nottingham), and Dr David Turner (University of Nottingham) for their contributions to the expert interviews. 
medRxiv preprint doi: https://doi.org/10.1101/2021.03.24.21254124; this version posted April 22, 2021. The copyright holder for this preprint (which was not certified by peer review) is the author/funder, who has granted medRxiv a license to display the preprint in perpetuity.

All rights reserved. No reuse allowed without permission.

\section{References}

[1] https://www.worldometers.info/coronavirus/countries-where-coronavirus-has-spread/ [Accessed 09/02/2021].

[2] Pan K-Y, Kok AAL, Eikelenboom M, Horsfall M, Jörg F, Luteijn RA, et al. The mental health impact of the COVID-19 pandemic on people with and without depressive, anxiety, or obsessive-compulsive disorders: a longitudinal study of three Dutch case-control cohorts. The Lancet Psychiat. 2021;8:121-9.

[3] https://www.ipsos.com/en/global-attitudes-covid-19-vaccine-october-2020 [Accessed 09/02/2021].

[4] Paul E, Steptoe A, Fancourt D. Anti-vaccine attitudes and risk factors for not agreeing to vaccination against COVID-19 amongst 32,361 UK adults: Implications for public health communications. medRxiv. 2020:2020.10.21.20216218.

[5] Loomba S, de Figueiredo A, Piatek SJ, de Graaf K, Larson HJ. Measuring the Impact of Exposure to COVID-19 Vaccine Misinformation on Vaccine Intent in the UK and US.

medRxiv. 2020:2020.10.22.20217513.

[6] The Sage Working Group.

https://www.who.int/immunization/sage/meetings/2014/october/1_Report_WORKING_GRO UP_vaccine_hesitancy_final.pdf. 2014.

[7] Robertson E, Reeve KS, Niedzwiedz CL, Moore J, Blake M, Green M, et al. Predictors of COVID-19 vaccine hesitancy in the UK Household Longitudinal Study. medRxiv.

2021:2020.12.27.20248899.

[8] Anderson RM, Vegvari C, Truscott J, Collyer BS. Challenges in creating herd immunity to SARS-CoV-2 infection by mass vaccination. The Lancet. 2020;396:1614-6.

[9] Abdullahi LH, Kagina BM, Ndze VN, Hussey GD, Wiysonge CS. Improving vaccination uptake among adolescents. Cochrane Database Syst Rev. 2020;1:Cd011895. 
medRxiv preprint doi: https://doi.org/10.1101/2021.03.24.21254124; this version posted April 22, 2021. The copyright holder for this preprint (which was not certified by peer review) is the author/funder, who has granted medRxiv a license to display the preprint in perpetuity.

All rights reserved. No reuse allowed without permission.

[10] Frascella B, Oradini-Alacreu A, Balzarini F, Signorelli C, Lopalco PL, Odone A.

Effectiveness of email-based reminders to increase vaccine uptake: a systematic review.

Vaccine. 2020;38:433-43.

[11] Bisset KA, Paterson P. Strategies for increasing uptake of vaccination in pregnancy in

high-income countries: A systematic review. Vaccine. 2018;36:2751-9.

[12] Dubé E, Gagnon D, MacDonald NE. Strategies intended to address vaccine hesitancy:

Review of published reviews. Vaccine. 2015;33:4191-203.

[13] Bach AT, Kang AY, Lewis J, Xavioer S, Portillo I, Goad JA. Addressing common barriers in adult immunizations: a review of interventions. Expert Rev Vaccines.

2019;18:1167-85.

[14] Jia R, Ayling K, Chalder T, Massey A, Broadbent E, Coupland C, et al. Mental health in the UK during the COVID-19 pandemic: cross-sectional analyses from a community cohort study. BMJ Open. 2020;10:e040620.

[15] Adebisi YA, Alaran AJ, Bolarinwa OA, Akande-Sholabi W, Lucero-Prisno DE. When it is available, will we take it? Public perception of hypothetical COVID-19 vaccine in Nigeria. medRxiv. 2020:2020.09.24.20200436.

[16] Fisher KA, Bloomstone SJ, Walder J, Crawford S, Fouayzi H, Mazor KM. Attitudes Toward a Potential SARS-CoV-2 Vaccine : A Survey of U.S. Adults. Ann Intern Med. 2020;173:964-73.

[17] Fu C, wei Z, Pei S, Li S, Sun X, Liu P. Acceptance and preference for COVID-19 vaccination in health-care workers (HCWs). medRxiv. 2020:2020.04.09.20060103. [18] Gadoth A, Halbrook M, Martin-Blais R, Gray A, Tobin NH, Ferbas KG, et al. Assessment of COVID-19 vaccine acceptance among healthcare workers in Los Angeles. medRxiv. 2020:2020.11.18.20234468. 
medRxiv preprint doi: https://doi.org/10.1101/2021.03.24.21254124; this version posted April 22, 2021. The copyright holder for this preprint (which was not certified by peer review) is the author/funder, who has granted medRxiv a license to display the preprint in perpetuity.

All rights reserved. No reuse allowed without permission.

[19] Grech V, Bonnici J, Zammit D. Vaccine hesitancy in Maltese family physicians and their trainees vis-à-vis influenza and novel COVID-19 vaccination. Early Hum Dev. 2020:105259.

[20] Hacquin A, Altay S, de Araujo E, Chevallier C, Mercier H. Sharp rise in vaccine hesitancy in a large and representative sample of the French population: reasons for vaccine hesitancy. PsyArXiv. 2020.

[21] Kwok KO, Li KK, Wei WI, Tang A, Wong SYS, Lee SS. Are we ready when COVID19 vaccine is available? Study on nurses' vaccine hesitancy in Hong Kong. medRxiv. 2020:2020.07.17.20156026.

[22] Pogue K, Jensen JL, Stancil CK, Ferguson DG, Hughes SJ, Mello EJ, et al. Influences on Attitudes Regarding Potential COVID-19 Vaccination in the United States. Vaccines (Basel). 2020;8.

[23] Sherman SM, Smith LE, Sim J, Amlôt R, Cutts M, Dasch H, et al. COVID-19 vaccination intention in the UK: results from the COVID-19 vaccination acceptability study (CoVAccS), a nationally representative cross-sectional survey. Hum Vaccin Immunother. 2020:1-10.

[24] Williams L, Gallant AJ, Rasmussen S, Brown Nicholls LA, Cogan N, Deakin K, et al. Towards intervention development to increase the uptake of COVID-19 vaccination among those at high risk: Outlining evidence-based and theoretically informed future intervention content. Br J Health Psychol. 2020;25:1039-54.

[25] Gale, R.C., Wu, J., Erhardt, T. et al. Comparison of rapid vs in-depth qualitative analytic methods from a process evaluation of academic detailing in the Veterans Health Administration. Implementation Sci. 2019;14;11. https://doi.org/10.1186/s13012-019-0853-y [26] Rollnick S, Miller WR, CC. B. Motivational interviewing in health care. Helping patients change behavior. New York: The Guilford Press; 2008. 
[27] Mbuagbaw L, Ye C, Thabane L. Motivational interviewing for improving outcomes in youth living with HIV. Cochrane Database Syst Rev. 2012.

[28] Gagneur A. Motivational interviewing: A powerful tool to address vaccine hesitancy. Can Commun Dis Rep. 2020;46:93-7.

[29] Lawes-Wickwar S, Ghio D, Tang MY, Keyworth C, Stanescu S, Westbrook J, et al. A Rapid Systematic Review of Public Responses to Health Messages Encouraging Vaccination against Infectious Diseases in a Pandemic or Epidemic. Vaccines (Basel). 2021;9.

[30] Yardley, L., Morrison, L., Bradbury, K. \& Muller, I. The person-based approach to intervention development: application to digital health-related behavior change interventions. J. Med. Internet Res. 2015;17; e30.

[31] Nielsen J. Estimating the number of subjects needed for a thinking aloud test. Int. J. Hum. Comput. Stud. 1994;41;385-97

[32] Tricco AC, Antony J, Zarin W, Strifler L, Ghassemi M, Ivory J, et al. A scoping review of rapid review methods. BMC Med. 2015;13:224.

[33] Tricco AC, Lillie E, Zarin W, O'Brien KK, Colquhoun H, Levac D, et al. PRISMA Extension for Scoping Reviews (PRISMA-ScR): Checklist and Explanation. Ann Int Med. 2018;169:467-73.

[34] https://www.equator-network.org/library/reporting-guidelines-underdevelopment/reporting-guidelines-under-development-for-systematic-reviews/ [Accessed 05/03/2021]. 